\title{
Driven to diffraction
}

\section{How Lawrence Bragg and his father used X-rays to solve crystal structures.}

\section{Light is a Messenger: the Life and Science of William Lawrence Bragg \\ by Graeme K. Hunter \\ Oxford University Press: 2004. 320 pp.

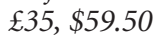 \\ Kenneth C. Holmes}

As a child I was enthralled by William Henry Bragg's Concerning the Nature of Things, which answers simply the question recently put to me by my granddaughter: "What are atoms and molecules?". Both the author and his son William Lawrence Bragg were in their time resident professor at the Royal Institution of Great Britain in London, and both had an unusually well developed ability to communicate with school-children. Their joint Nobel prize, awarded in 1915, was for showing how X-ray diffraction could be used to determine the structure of crystalline substances. It is no coincidence that the title of William Bragg's book is a translation of De rerum natura, in which Lucretius set out his atomic theory of matter. However, Lucretius would have to wait nearly 2,000 years for the Braggs to show that he was right.

Lawrence was born in 1890 in Adelaide, Australia, where his father was a professor. He was a gifted pupil and became a very young member of the sixth form at St Peter's College. However, ignored by his older classmates, he was driven to finding solitary occupations, such as collecting and cataloguing sea-shells. At the age of 16 he proceeded to Adelaide University, where he took a degree in mathematics with first-class honours in 1908.

His father accepted an appointment as a professor at Leeds University, and in 1909 the family came to England. Lawrence entered Trinity College, Cambridge, taking firstclass honours in the natural-science Tripos in 1912, and started his research under J. J. Thomson at the Cavendish Laboratory. His father had awakened his interest in Max von Laue's work on the diffraction of X-rays by crystals. Lawrence's studies of von Laue's diffraction patterns led him to postulate that zinc sulphide was based on a face-centredcubic lattice, an amazing piece of insight. It was during this period that he formulated Bragg's law. Intuitively much simpler than the von Laue equations, it allows an estimate, by inspecting simple crystals, of how strong a particular X-ray reflection would be.

Lawrence started to work with his father in the summer of 1913. Although the older Bragg was still principally interested in $\mathrm{X}$-ray spectra, his X-ray spectrometer also

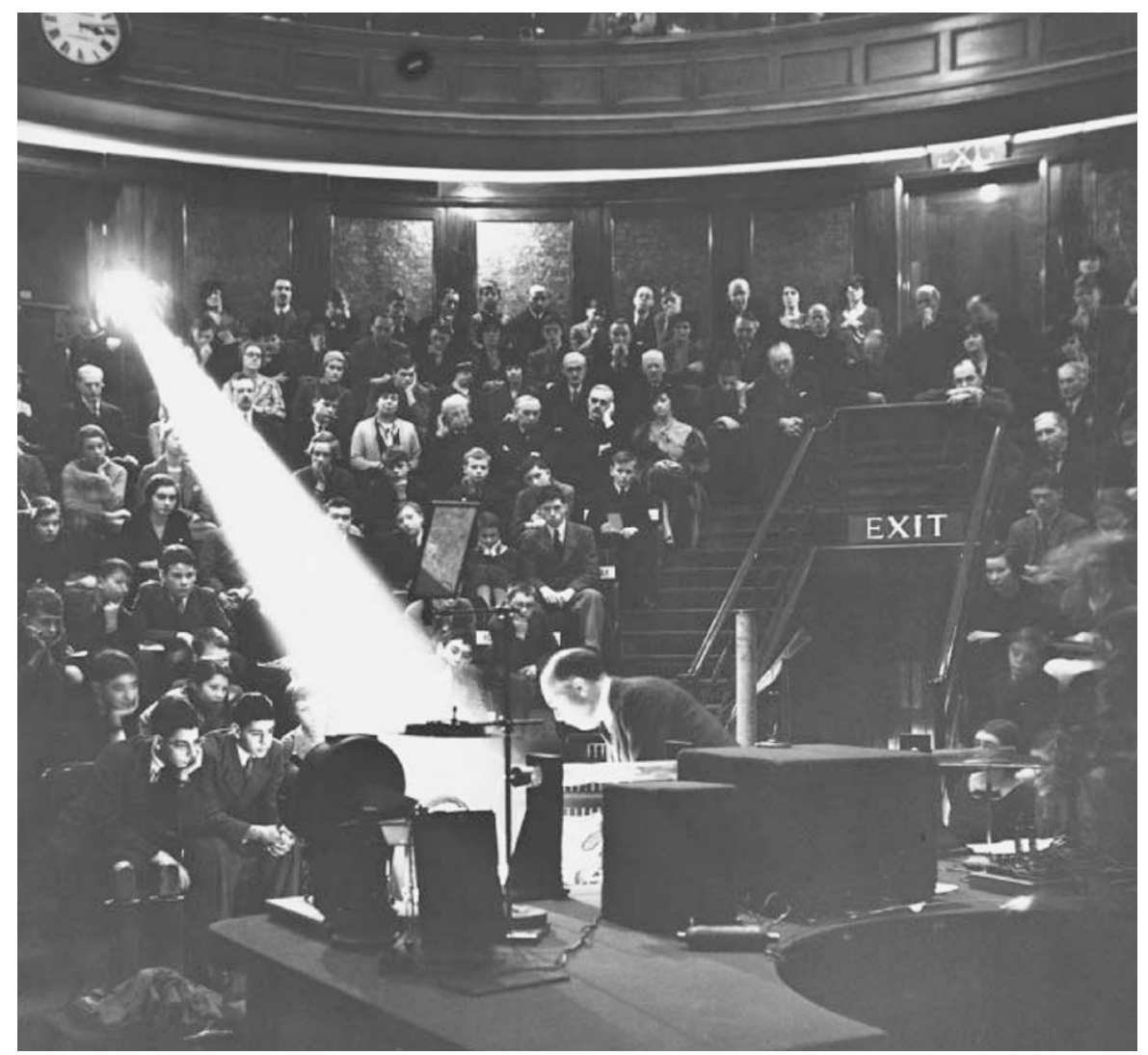

Leading light: Lawrence Bragg , like his father, was resident professor at the Royal Institution.

provided a powerful tool for crystal analysis. After showing its power by analysing the structure of diamond, William continued to establish the relations between $\mathrm{X}$-ray spectra and the $\mathrm{K}$ and $\mathrm{L}$ absorption edges, and Lawrence concentrated on interpreting crystal structures. It was the publication of their results in abridged form in 1915 that earned the two Braggs the Nobel prize for physics in 1915. At just 25 years of age, Lawrence was the youngest ever Nobel laureate.

During the First World War, Lawrence served as a technical adviser on sound ranging in France, where he made a number of friends, including R. W. James. Lawrence was appointed Langworthy professor of physics at Manchester University in 1919, and in 1921 he married Alice Hopkinson. He was neither a skilled a lecturer nor a good administrator, however, and relied on James to keep the department running. But the remarkable science continued, with structures of the silicates and the optical theory of the diffraction of X-rays. The lab was abuzz with famous visitors. His father was then at the Royal Institution in London, presiding over Bill Astbury's unruly genius. Together with Kathleen Lonsdale and John Desmond Bernal, they were working out how to do X-ray structure analysis of complex organic molecules. Between them, the Braggs had it sewn up.

After a year as director of the National Physical Laboratory in 1937-38, Lawrence became Cavendish professor of physics at Cambridge University (1938-53), finding Rutherford a hard act to follow, as he had at Manchester. Lawrence's avuncular style of lecturing was not to the liking of the students, and his crystallography did not please the nuclear physicists. Realizing that Cambridge did not have the resources to become an accelerator lab, he encouraged the study of radio astronomy and protein crystallography, which led to a plethora of Nobel prizes. His support for Max Perutz and his hopeless attempts to solve the Patterson function of haemoglobin was initially difficult to fathom, and later entailed tolerating Francis Crick's penetrating voice. Lawrence's memorable Edwardian epithet concerning Crick was that he was given to "doing someone else's crossword". All was forgiven when Crick and Jim Watson figured out the structure of DNA, however - not because Lawrence had any interest in biology, but because they beat his rival Linus Pauling. Nevertheless, Lawrence contributed a lot 
to Perutz's subsequent success with protein structure. On a bizarre level, he was interested in crystal dislocations and, much to the amazement of his colleagues and first-year undergraduates, was able to simulate their motion with rafts of bubbles.

On retirement from the Cavendish, Lawrence became resident professor at the Royal Institution. There he built up a powerful group, led by David Phillips, that solved the first structure of an enzyme. In his lifetime, Lawrence saw X-ray crystallography grow from the seed he helped germinate to a method of solving the structures of the largest macromolecules.

The subtitle of Graeme Hunter's book refers to Lawrence's "life and science". The 'life' section is full of anecdotes and makes fascinating reading. Hunter captures the lonely schoolboy and tells of Alice Bragg - who some of us remember as a rather formidable justice of the peace - as a lively young flapper. He brings out Lawrence as an artist. Moreover, although Lawrence tried to avoid confrontation, his appointment to succeed Edward Andrade at the Royal Institution was accompanied by bad feelings and tension, which is fairly portrayed and analysed by Hunter.

The science is more of a problem. Most of it seems fairly accurate, but one or two sections reminded me of the description of the farm in Stella Gibbons' Cold Comfort Farm, in which the detailed geometrical descriptions resist synthesis. Hunter, who is not a crystallographer, must be commended for his brave attempt to put the science where it really belongs. However, his lack of a real understanding of diffraction theory shows up in numerous mini-howlers.

For example: " $n \lambda=2 d \sin \theta \ldots$ this was the famous Bragg equation. However, there was nothing really novel about it ... for a line grating, $2 e \sin \theta=n \lambda$. . Apart from the $\theta$ being different, Hunter misses the point first made by von Laue that diffraction from a threedimensional lattice is subject to constraints not pertinent for a one-dimensional grating. The Bragg law imposes two conditions: specular reflection and the Bragg equation.

Hunter's lack of comprehension leads to an even bigger howler in Figure 0.2 in the introduction, which is supposed to help the lay reader. Hunter's putative Bragg reflections do not satisfy the Bragg equation, and moreover show that high-order reflections come out at low diffraction angles, and loworder reflections come out at high angles of diffraction; this is exactly the wrong way round. The strange thing is that a bit later, in Figure 2.7, he gets it right. The book, which could easily have been rescued by rigorous professional editing, is already in need of a second edition.

Kenneth C. Holmes is in the Department of Biophysics, Max-Planck-Institut für Medizinische Forschung, Heidelberg 69120, Germany.

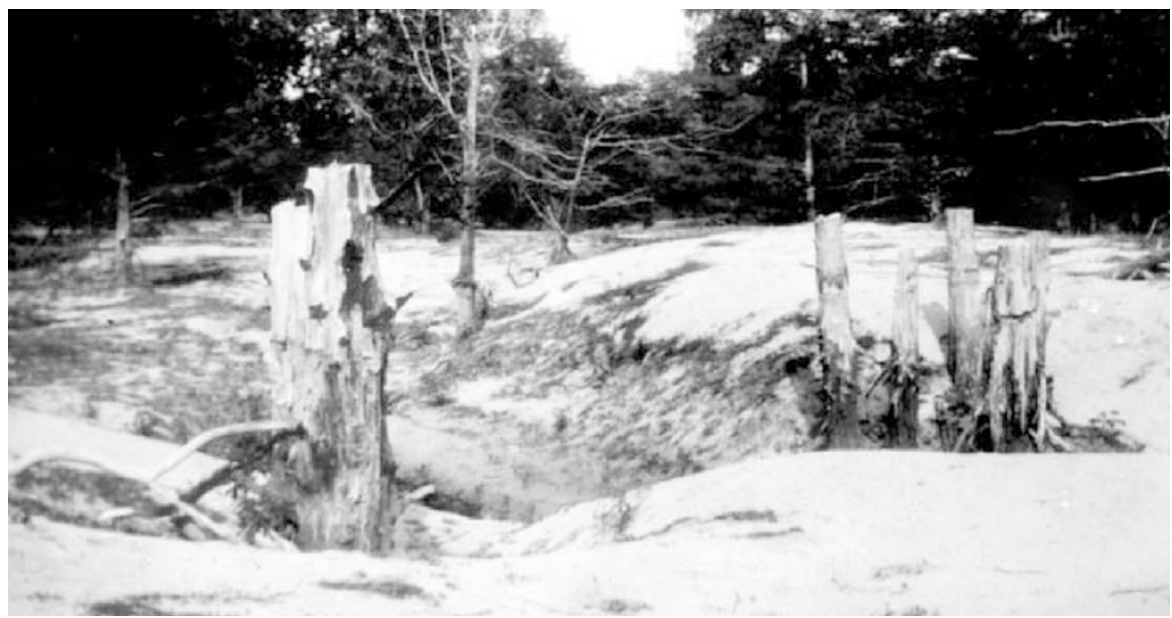

Driving force: the New Madrid earthquakes moved the earth, but did they reshape geology?

\section{Shaking up seismology}

The Big One: The Earthquake That Rocked Early America and Helped Create a Science

by Jake Page \& Charles Officer

Houghton Mifflin: 2004. 220 pp. \$24

\section{Naomi Oreskes}

In the winter of 1811-12, three major earthquakes struck an area of the North American mid-continent in rapid succession. According to eye-witnesses, the ground ruptured profoundly in numerous locations, lakes appeared where there had been none, and the mighty Mississippi River flowed backwards. The earthquakes, felt as far away as Montreal in Canada, affected an area of more than a million square miles. Their magnitudes have since been estimated at between 7.8 and 8.3, greater than the 7.6 of the famous San Francisco earthquake of 1906, making them among the most powerful quakes to strike the United States in recorded history.

The United States was then a young and sparsely settled country, and the theory of plate tectonics was far in the future, so there is no meaningful sense in which these earthquakes could have been considered "anomalous" at the time. Nonetheless, they are scientific anomalies now: the theory of plate tectonics explains large earthquakes as the release of stress built up as the Earth's crustal plates slowly grind past one another, but the quakes of New Madrid (to rhyme with Hagrid) occurred nowhere near a plate boundary.

If the theory of plate tectonics does not explain 'intra-plate' earthquakes, then what caused the New Madrid quakes? And why hasn't this conspicuous anomaly caused a crisis for the current theory? These are intriguing questions, and The Big One begins with the promise of answering them. Unfor- tunately, that promise remains unfulfilled.

The book opens with a fast-paced description of the events of that winter and the background to European settlement in the region. It then changes tack: most of the rest of the book is a historical discussion of developments in the Earth sciences, leading to present-day theories of the origins of the New Madrid events. Sadly, this material is filled with factual errors and presents little that is not better treated elsewhere.

It would be tedious to recount the numerous mistakes and misrepresentations; a few will suffice to make the point. Lord Kelvin did not originate the idea that Earth was progressively cooling; that honour, if that's what it is, belongs to Georges-Louis Leclerc de Buffon, Immanuel Kant and Pierre Laplace. Isostasy - the theory that the Earth's crust sits in hydrostatic equilibrium on a denser substrate - is not the theory of glacial rebound; glacial rebound is merely one example of an isostatic effect. Alfred Wegener, the author of continental drift theory, did not die attempting to bring help to stranded members of his 1930-31 Greenland expedition, but on a trip to equip an inland observation station (see http:// www.awi-bremerhaven.de/AWI/geschichte/ germanexpedition-e.html). And no one in the 1920s pejoratively called Wegener's work "geopoetry" - that term was introduced later by the Dutch geophysicist J. H. F. Umbgrove as an approbative term for creative speculation, a concept later used to great effect by US geologist Harry Hess.

The authors' treatment of continental drift and plate tectonics is particularly beset by peculiar biases. They perpetuate the well worn but erroneous view that continental drift was rejected for lack of a causal mechanism, but in fact mantle convection was widely discussed in the 1920s and 1930s as a plausible mechanism. They credit the idea of mantle convection to seismologist Beno Gutenberg at Caltech in the 1950s, but its earliest prominent and credible advocate was the British geologist Arthur Holmes, 


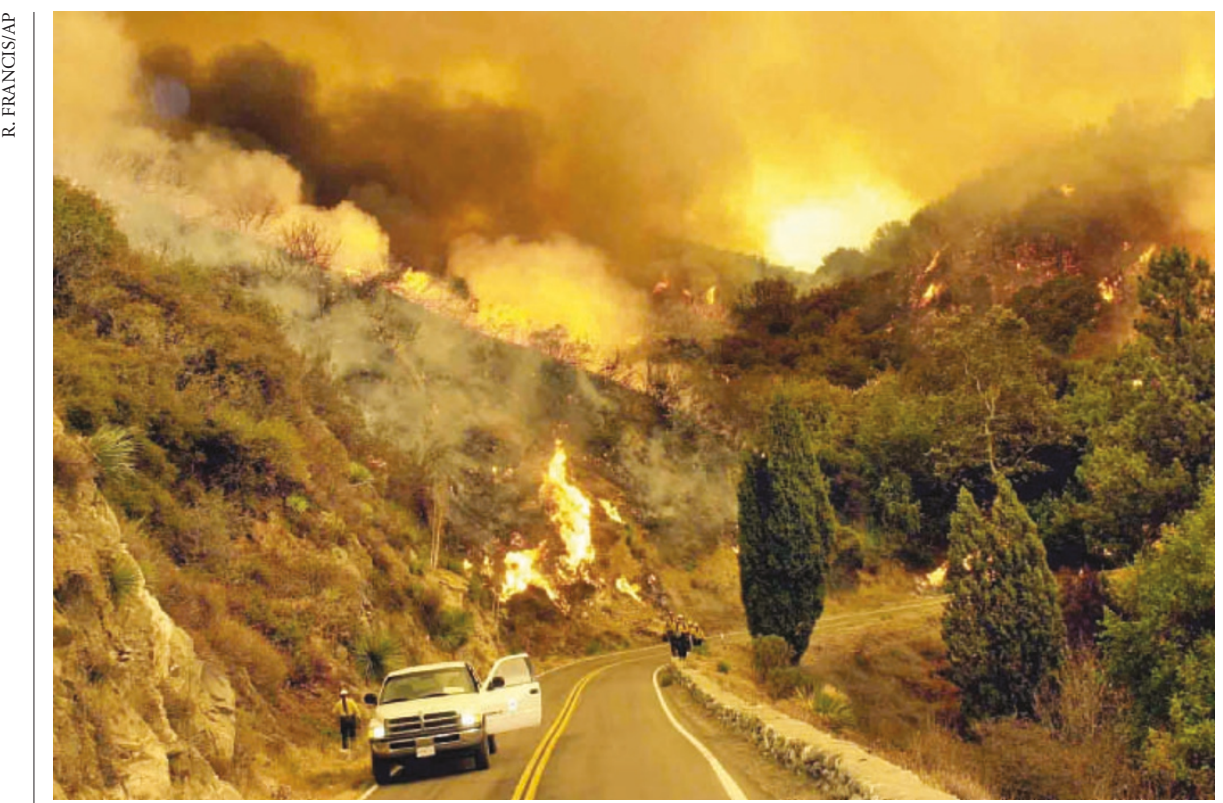

California burning: US wildfire policy is caught up in a greater clash over the value of wildlands.

public wildlands of the western United States, which are the scene of catastrophic wildfires wrought in equal part by nature and by the putative failings of the people charged with their management. The "pyric transition" the switch from 'natural' biomass fire to the industrial use of fossil fuels - is briefly recapitulated. Pyne recounts its progression from "free-running" fire, experienced by indigenous peoples, to European colonial exploitation (including overgrazing, clearing, logging and mining), the creation of reserves, and the advent of bureaucratic command and control.

The core of the book is an account of the four fundamental pillars of fire management: suppression, 'let burn', prescribed fire, and fuel treatment. Pyne counsels that relying on any one alone is doomed to failure, as history has shown. They all have their place in solving the fire problem, but in what particular mix? Beyond noting that different mixes are likely to be required in different ecosystems at different times and places, Pyne offers no comprehensive solution.

His vision, focused on ponderosa pine forests, is heavily qualified. Forceful arguments, such as the need for mechanical thinning and the re-introduction of surface fires, are tempered by caveats. For example, wildfires are inevitable and serve useful ecological purposes, and anyway, the best solution depends on the locality, as crown fires may be required in chaparral and high-altitude conifer forests. At times the juxtaposition of solutions is breathtaking: devolution of planning responsibility to the community on one hand, with increased government regulation of urban design on the other. Pyne does, however, paint a slick picture of climate change and the consequences of burning fossil fuels, and of the international pressures that may be brought to bear on US fire management to reduce emissions.

Ultimately, Tending Fire succeeds as a visceral and widely accessible account of the problem of wildfires. Pyne does not solve it but lays it out in all its maddening, selfcontradictory splendour. His attempts to sketch a way forward, although useful, amplify the paradoxes and the choices available. Wisely, he counsels that, at best, both art and science can illuminate the consequences of differing choices but are not surrogates for decision-making.

The book concludes with a call for a biological theory of fire. This is a noble effort but the sketch offered is disappointing. The nostrum that fire is a by-product of life (biomass) is useful, but falls short. Fire is frustrating because we do not properly understand how it works at the spatial and temporal scales at which we confront it. Physical and ecological knowledge is shackled within micro-scale, reductionist paradigms that are inadequate for understanding fire and its consequences on a larger scale. Coping with fire is about understanding and manipulating forms of heterogeneity and biophysical feedbacks that we have barely grasped and that are not amenable to 'bottom-up' scientific enquiry. It is about recognizing that fire poses both risks and benefits at several levels. Compromises and tradeoffs must be engineered accordingly, but the functional knowledge required for effective management is lacking. Fire is a transcendent phenomenon in both biophysical and socio-political senses. Tending Fire contributes to our awareness of this, but there is a long road ahead.

Ross Bradstock is at the Bushfire Co-operative Research Centre and the Biodiversity

Conservation Science Section, New South Wales Department of Environment and Conservation, Box 1967, Hurstville, NSW 2220, Australia.
New in paperback

Life on a Young Planet: The First Three Billion Years of Evolution on Earth by Andrew Knoll

Princeton University Press, £12.50, \$18.95

"Expresses better than most the bumptious vitality and sheer fun of open-minded research." Stephan Bengston, Nature 423, 481 (2003).

\section{Eating Apes}

by Dale Peterson

University of California Press, £15.95, \$15.95

An account of efforts to publicize the trade in wild meat, "now perceived as one of the most important threats to global biodiversity." Guy Cowlishaw, Nature 424, 131 (2003).

\section{The Discovery of Global Warming}

by Spencer Weart

Harvard University Press, £9.95, \$14.94, €13.90 "Up-to-date, balanced historically, beautifully written, and short and to the point."

Steven Schneider, Nature 427, 197 (2004).

\section{Memory from A to $\mathbf{Z}$}

by Yadin Dudai

Oxford University Press, £19.95, \$39.50

"An engaging, informative and sometimes playful collection of essays"

Larry Squire, Nature 423, 119 (2003).

The Man Who Changed Everything: The Life of James Clerk Maxwell

by Basil Mahon

Wiley, £8.99, \$14.95, €13.50

"Not merely an absorbing account of Maxwell's life but also an explanation of why his work is at the foundation of the modern world." John Maddox, Nature 425, 765 (2003).

\section{The Particle Odyssey: A Journey to the Heart of Matter}

by Frank Close, Michael Marten

and Christine Sutton

Oxford University Press, £17.95, \$25

"A beautifully illustrated and eminently readable introduction to high-energy physics" Ken Peach, Nature 419, 879 (2002).

\section{DNA: The Secret of Life}

by James $D$. Watson with Andrew Berry Knopf, $\$ 24.95$

"More inclusive and better reading than similar attempts by science journalists."

Maxine Singer, Nature 422, 809 (2003).

\section{Correction}

In his review of Graeme K. Hunter's book Light is a Messenger (Nature 431, 1037-1038; 2004), Kenneth C. Holmes stated that there was an error in Figure 0.2 in the book. In fact, this figure is intended to show a polychromatic, rather than a monochromatic, diffraction experiment, in which case the Bragg reflections are correctly displayed. 